\title{
PRAKTIK MEMPEKERJAKAN ANAK DALAM PERSPEKTIF HUKUM ISLAM DAN HUKUM POSITIF SERTA PENGARUHNYA TERHADAP PERKEMBANGAN EMOSI ANAK
}

\author{
Sulastri \\ Program Studi Psikologi Universitas Muhammadiyah Lampung \\ sulastri2270@gmail.com
}

\begin{abstract}
This research aims to find out and analyze the factors that lead to the child labour practice, knowing its forms, analyzed according to the perspective of Islamic law and positive law, looking for their influence on children's emotional development. Data collected by interview using inductive analysis. Research results: 1. The causes of the practice of child labor are economic factors, trafficking, environmental influences, low education, and the absence of a clear legal protection, 2 . The forms of child labor practices are AYLA (prostituted children), child domestic help (PRTA), plantation workers, construction workers, beggars, scavengers, pelvic workers in ports and terminals, newspaper sellers, washing and steam workers. 3. Prohibition of employing children in positive law is explained in the principles and objectives of Law No. 13 of 2003 in Article 2, and Article 68-74, contained in the Decree of the Minister of Manpower and Transmigration of the Republic of Indonesia Number KEP-235 / MEN / 2003. In Islamic law supported by naqli arguments and theorems of 'aqli, and contained in the Word of Allah SWT which means "and do not trouble them to narrow their hearts" and hadith which means "may not make harm and may not cause harm to others in Islam ". Child labour practice influences child's emotional development which will develop a negative scheme that influences the experience that will be interpreted by themselves.
\end{abstract}

Keywords: Child Labour, Perspective, Islamic Law, Positive Law, Children's Emotions

\begin{abstract}
ABSTRAK
Penelitan ini bertujuan untuk mengetahui dan menganalisis faktor penyebab terjadinya praktik mempekerjakan anak, dan mengetahui bentuk-bentuknya, dianalisis menurut perspektif hukum Islam dan hukum positif, mencari pengaruhnya terhadap perkembangan emosi anak. Metode penelitian yang digunakan wawancara, dengan pendekatan kualitatif dan kesimpulan menggunakan analisis induktif. Hasil penelitian:1. Faktor penyebab terjadinya praktik mempekerjakan anak adalah faktor ekonomi, traficking, pengaruh lingkungan, rendahnya pendidikan, dan tidak adanya paying hokum yang jelas, 2. Bentuk praktik mempekerjakan anak adalah AYLA (anak yang dilacurkan), pembantu rumah tangga anak (PRTA), buruh diperkebunan, buruh bangunan, pengemis, pemulung, buruh panggul di pelabuhan dan terminal, penjual koran, buruh cuci dan steam. 3. Larangan Mempekerjakan anak dalam hukum positif dijelaskan dalam asas dan tujuan dari UU no 13 tahun 2003 dalam Pasal 2, dan pasal 68-74, terdapat di dalam Keputusan Menteri Tenaga Kerja dan Transmigrasi Republik Indonesia Nomor KEP-235/MEN/2003. Dalam Hukum Islam didukung dalil naqli dan dalil 'aqli, dan terdapat dalam Firman Allah SWT yang artinya "dan janganlah kamu menyusahkan mereka untuk menyempitkan hati mereka" dan hadis yang artinya "tidak boleh membuat mudarat dan tidak boleh menimbulkan mudarat bagi orang lain di dalam Islam". Praktik mempekerjakan anak berpengaruh terhadap perkembangan emosi anak dengan mengembangkan skema negatif yang berpengaruh pada pengalaman yang akan diinterpretasikannya.
\end{abstract}

Kata Kunci: Mempekerjakan Anak, Perspektif, Hukum Islam, Hukum Positif, Perkembangan Emosi 


\section{PENDAHULUAN}

Mempekerjakan aanak di bawah umur, belakangan ini menjadi fenomena yang marak di manamana. Fakta ini sangat jelas, terutama semenjak krisis ekonomi menera Indonesia, dan kemiskinan pada masyarakat semakin bertambah. Anak-anak tidak dapat menikmati masa anak-anaknya, seperti bermain, kehilangan masa depan, dikarenak harus bekerja dan anak-anak kehilangan waktu untuk berkumpul dengan keluarganya, dikarenakan mempunyai tanggung jawab terhadap pekerjaan, sama halnya seperti orang dewasa.

Anak-anak telah bekerja yang tidak sesuai dengan usiana, harus membantu untuk memenuhi kebutuhan kluarga, sehingga tidak dapat lagi mendapatkan hak sesuai dengan usianya, seperi sekolah, bermain dan yang lainnya, yang berguna untuk mempersiapkam masa depannya. Jumlah anak 0-18 tahun pada tahun 2013 sebanyak (2,95 juta org) atau 38,05\% dari total penduduk Lampung 7.767 .312 orang.. Jumlah pekerja anak sebanyak 183.602 orang, terdiri dari 36.146 orang perempuan dan127.456 orang laki-laki. Data di BPS dan Dinas Sosial Provinsi Lampung (2013), jumlah anak penyandang masalah sosial sebanyak 32.893 orang antara lain anak jalanan sebanyak 1.841 orang, anak terlantar 30.482 orang, korban tindak kekerasan 570 org.

Realita saat ini, masih banyak terjadi praktik mempekerjakan anak, seperti dipekerjakan di jalanan, di rumah majikan, di perkebunanan dan di pabrik. Banyak juga terjadi kekerasan fisik, kekerasan seksual, eksploitasi ekonomi, aborsi, bullying, mutilasi, pembunuhan bayi, dan balita bergizi buruk. Secara umum, di semua lapisan masyarakat masih sering terlihat adanya pemaksaan kehendak orang tua terhadap anaknya, hal ini merupakan akibat kurang dihargainya pendapat anak atau bahkan menjadikan anak hanya sebagai obyek semata Menurut Hukum, praktik pekerja anaka adalah satu bentuk pelanggaran hukum.

Pemerintah sudah memiliki Undang-Undang yang bisa melindungi anak-anak dari praktek ini. Setidaknya ada dua UU yang bisa digunakan yaitu UU No. 23 Tentang Perlindungan Anak, serta UU No. 13 Tentang Ketenagakerjaan, UU No 4 Tahun 1979 tentang Kesejahteraan Anak. 
Dalam Undang-Undang Nomor 23 Tahun 2002 Tentang Perlindungan Anak, jelas dicantumkan bahwa hak anak disebutkan anak berhak mendapatkan hak hidup, hak tumbuh kembang,di dalam pasal 4 sampai dengan pasal 18, yaitu yang berisikan hak-hak dasar anak yang harus dipenuhi. Oleh karena itu anak sangat memerlukan dan membutuhkan hak-hak tersebut, dikarenakan berbagai alasan yang mendukung untuk pertumbuhan dan perkembangan anak tersebut.

Terdapat juga hak untuk berpartisipasi , seorang anak berhak berpandapat atas keputusan orang tuanya maupun lingkungannya. Dalam hubungannya dnegan praktik mempekerjakan anak, terdapat pasal yang berbubahwa perusahaan dilarang memepekrjakan anak di bawah usia 14 tahun. Artinya bahwa anak-anak di bawah umur harus dilindungi dan dilarang mempekerjakannya. Dan sebaliknya bahwa anak harus terpenuhi segala hak dasarnya sperti terdapat dalam undang-undang.

Islam telah menetapkan syariat yang sempurna tentang anak-anak, yaitu sejak anak dilahirkan, bahkan sebelum dilahirkan ke dunia dan sebelum diletakkan ke dalam rahim ibu. Hak-hak sudah ditetapkan, hal ini menyangkut pengasuhan, perhatian, etika dan pendidikan dan yang lainnya. Hakhak ini harus dipenuhi oleh setiap orang yang memegang tanggung jawab, baik keluarga, masyarakat maupun negara.

KHA (Konvensi Hak Anak) merupakan intrumen Mengenai hak anak, secara umum berbagai negara saat ini berpegang pada apa yang telah digariskan oleh PBB. Diantaranya yang telah disebutkan dalam piagam PBB (Universal Declaration of Human Right s) adalah mengenai hak asasi anak yang dirinci sesuai dengan kebutuhan dan kepentingannya, berdasarkan perkembangan fisik dan mentalnya.

Sebagaimana manusia yang lainnya, setiap anak memiliki kebutuhan-kebutuhan dasar yang menuntut untuk dipenuhi, srhingga anak dapat tumbuh dan berkembang secara sehat dan wajar. Menurut Muhidin (2003) bahwa kebutuhan dasar yang sangat penting bagi anak adalah adanya hubungan orang tua dan anak, yang sehat dimana kebutuhan anak seperti: perhatian dan kasih sayang yang continue, perlindungan, dorongan, dan pemeliharaan harus dipenuhi oleh orang tua. Dan 
menurut Andi (2008) dalam rangka penyelenggaraan perlindungan anak, negara dan pemerintah bertanggung jawab menyediakan fasilitas dan eksabilitas bagi anak, terutama dalam menjamin pertumbuhan dan perkembangannya secara optimal dan terarah. Dengan demikian bagaimana semua hak anak akan terpenuhi, jika anak dalam kesehariannya selalu disibukkan dengan tanggung jawab sebagai pekerja, jelas tidak bias bersekolah dan bermain, tidak bias berkumpul dengan keluarga yang seharusnya tempat yang nyaman bagi anak tersebut untuk berkumpul, bercengkerama, bersendagurau dan bercanda.

Anak Sebagai generasi penerus bangsa, selayaknya mendapatkan hak-hak dan kebutuhankebutuhannya secara memadai. Sebaliknya anak bukanlah objek atau sasaran tindakan kesewenangwenangan, dan perlakuan yang tidak manusiawi dari siapapun atau pihak manapun. Anak yang dinlai rentan terhadap tindakan ketidaksewenangan dari atasannya di tempat kerja atau majikan di mana anak sebagai pembantu rumah tangga anak bekerja, seharusnya anak-anak di rawat, diasuh, dididik dengan sebaik-baiknya, agar tumbuh dan berkembang secara sehat dan wajar.

Perlu disadari, bahwa permasalahaan praktik mempekerjakan anak bukanlah hal yang sederhana, penanggulangannya sangat memerlukan peran para pihak, karena hal ini bukanlah merupakan tanggung jawab orang tua saja, melainkan juga menjadi tanggung jawab Negara dan pemerintah serta masyarakat. Menyadari hal ini, maka dipandang perlu diadakan penelitian yang berjudul "Praktik mempekerjakan Anak dalam perspektif Hukum Islam dan Hukum Positif serta Pengaruhnya Terhadap Perkembangan Emosi Anak".

\section{METODE PENELITIAN}

Subyek dalam penelitian ini adalah anak usia 5 tahun sampai dengan 17 tahun, yang merupakan korban pekerjaan informal, dan wilayah hukumnya di Kota Bandar Lampung. Bentuk penelitian lapangan (field research) yang bersifat deskriptif, yaitu untuk mengambarkan secara sistematis, faktual dan mengenai fakta-fakta, sifat-sifat serta hubungan antar fenomena yang 
diselidiki (Nazir,2003). Bertujuan untuk mengungkapkan atau mendeskripsikan gejala yang telah ada dan atau sedang berlangsung (Nana Sudjana dan Awal Kusumah, 2000).

Pendekatan yang digunakan adalah kualitatif, yaitu untuk memahami fenomena tentang apa yang dialami oleh subyek penelitian, misalnya perilaku, persepsi, motivasi, tindakan (Moleong, 2005), digunakan untuk mengungkapkan kebenaran realitas yang ada, dan bagaimana senyatanya berjalan. (Mulyadi, Basuki dan Prabowo, 2019). Pendekatan kualitatif sebenrnya merupakan tata cara penelitian yang dapat memperoleh data deskriptif, yaitu apapun yang sebenarnya terjadi pada diri individu, baik secara tertulis atau lisan dan perilaku yang nyata.

Pendekatan yang dilakukan adalah kepada anak selaku pekerja, orang tua yang mempekerjakan anak, dan lembaga-lembaga yang berperan dalam menangani berbagai kasus mempekerjakan anak. Dilihat dari sifatnya, penelitian ini bersifat studi komparatif atau studi perbandingan antara hukum Islam dan hukum positif tentang praktik mempekerjakan anak. Pendekatan ini menempuh langkah-langkah sebagai berikut:

1) Identifikasi objek penelitian yang sesuai dengan kriteria dan didukung oleh berbagai dokumen yang sangat berhubungan.

2) Menginventarisir berbagai pasal, Undang-undang dan berbagai peraturan yang mempunyai hubungan dengan objek penelitian

3) Menginventarisir berbagai bentuk-bentuk mempekerjakan anak yang dilaksanakan oleh lembaga yang dijadikan tempat untuk mengadakan penelitian, dalam hal ini masalah mempekerjakan anak.

4) Setelah semua data terkumpul, kemudian melakukan deskripsi menurut hukum Islam maupun menurut hukum positif.

5) Menganalisis dampak psikologis mempekerjakan anak terhadap perkembangan emosi. 
Metode pengumpulan data merupakan cara bagaimana peneliti mendapatkan informasi yang diperlukan dalam penelitian (Arikunto, 2006). Adapun metode yang digunakan dalam peneliitian ini antara lain:

1) Observasi

Observasi adalah pengamatan dan pencatatan secara sistematis terhadap yang tampak pada objek penelitian (Arikunto, 2006). Menggunakan observasi non partisipan dengan cara pengamatan dilakukan dengan tidak mengambil bagian terhadap aktivitas yang diamati, sehingga penelitian ini cukup hanya melihat atau memperhatikan saja. Metode pengumpulan data ini penulis gunakan untuk memperoleh data tentang bentuk dan dampak praktik mempekerjakan anak.

2) Wawancara

Wawancara dibedakan menjadi dua macam, yaitu terstruktur dan tidak terstruktur (Margono, 2000). Dalam penelitian ini penulis menggunakan intervieu tidak terstruktur. Wawancara tidak terstruktur merupakan wawancara yang berbeda dengan terstruktur, dikarenakan penelitian ini bertujuan untuk menemukan informasi yang luas (Moelloeng, 2002).

3) Dokumentasi

Dengan metode ini, untuk mengaplikasikannya dengan cara membaca buku-buku atau jurnal terbit, serta dokumen-dokumen yang terkait dengan subyek penelitian.

Setelah diperoleh data-data dari lapangan maupun dokumentasi, kemudian data tersebut dioleh dan diproses melalui beberapa teknik pengolahan dan analisis data sebagai berikut: 
1) Edit

Sebelum diolah data yang telah diperoleh perlu diedit terlebih dahulu, dalam mengedit, dengan harapan informasi yang didapatkan dapat diperjelas dan dibaca, dan menghilangkan keraguan .(Nasir, 2003).

2) Klasifikasi

Klasifikasi merupakan langkah kedua dalam analisis data kualitatif, tanpa klasifikasi data maka kita tidak dapat mengetahui apa yang kita analisis. Selain itu kita tidak bias membuat perbandingan yang bermakna antara setiap bagian dari data.(Moelloeng, 2002). Tujuan dilakukan klasifikasi ini adalah untuk mengetahui dimana hasil wawancara diklasifikasikan berdasarkan kategori tertentu, yaitu berdasarkan pertanyaan dalam rumusan masalah, sehingga data yang diperoleh benar-benar memuat informs yang dibutuhkan dalam penelitian (Natsir, 2003).

3) Verifikasi.

Melakukan verifikasi (pengecekan ulang) terhadap data-data yang diperoleh dan diklarifikasikan tersebut, agar akurasi data yang telah terkumpul dapat diterima dan diakui kebenarannya oleh segenap pembaca, dilakukan dengan cara menemui subyek penelitian, untuk melakukan mencocokkan (Cross check) antara hasil wawancara dengan subyek penelitian yang satu dengan subyek yang lain, hal ini bertujuan supaya hasil penelitin dapat disimpulkan secara proporsional (Nazir, 2003).

4) Analisis

Analisis deskriptif kualitatif yaitu analisis yang menggambarkan keada atau status fenomena dengan kata-kata atau kalimat, kemudian dipisah-pisahkan menurut kategori tertentu untuk memperoleh kesimpulan. 
5) Penarikan Kesimpulan

Menarik kesimpulan dari hasil penelitian yang telah dilakukan melalui metode di atas, yang kemudian menghasilkan gambaran secara ringkas, jelas dan mudah dipahami tentang relasi antara realitas dan normatifitas, dengan menggunakan metode analisis deduktif induktif dan komparatif (Khotimah, 2007)

Metode pengumpulan data merupakan cara bagaimana peneliti memperoleh data yang diperlukan dalam penelitian (Arikunto, 2006). Adapun metode yang digunakan dalam peneliitian ini antara lain:

1) Observasi

Observasi adalah pengamatan dan pencatatan secara sistematis terhadap yang tampak pada objek penelitian (Arikunto, 2006). Walgito (2002) membagi observasi dalam dua bagian, yaitu observasi partisipan dan observasi nonpartisipan. Penelitian ini menggunakan observasi non partisipan yaitu pengamatan dilakukan dengan tidak mengambil bagian terhadap aktivitas yang diamati, sehingga penelitian ini cukup hanya melihat atau memperhatikan saja. Metode pengumpulan data ini penulis gunakan untuk memperoleh data tentang bentuk dan dampak praktik mempekerjakan anak.

2) Wawancara

Wawancara dibedakan menjadi dua macam, yaitu terstruktur dan tidak terstruktur (Margono, 2000). Dalam penelitian ini penulis menggunakan intervieu tidak terstruktur. Wawancara tidak terstruktur merupakan wawancara yang berbeda dengan terstruktur, dikarenakan penelitian ini bertujuan untuk menemukan informasi yang bukan baku atau informasi tunggal (Moelloeng, 2002). Selanjutnya Moelloeng, 2002) mengatakan bahwa hasil dari wawancara ini menekankan kekecualian, penyimpangan, penafsirkan tidak lazim, penafsiran kembali, pendekatan baru, pandangan ahli atau perspektif tunggal. 
Dalam proses wawancara tidak terstruktur jauh lebih bebas iramanya. Responden biasanya terdiri atas mereka yang terpilih saja, karena sifat-sifatnya yang khas, yang memiliki pengetahuan dan mendalami situasi, dan mereka yang lebih mengetahui informasi yang diperlukan. Pertanyaan dalam wawancara di sini mengalir, disesuaikan dengan keadaan dan ciri khas yang unik dari subyek penelitian.

3) Dokumentasi

Metode pengumpulan data berupa dokumentasi yang dimaksud adalah dokumen yang tertulis. Penulis mendapatkan data-data menggunakan metode ini dengan cara membca bukubuku atau jurnal terbitan serta dokumen-dokumen yang terkait dengan subyek penelitian. Hal ini dilakukan untuk mendapatkan pemahaman yang utuh terhadap suatu permasalahan yang sedang diteliti.

\section{HASIL PENELITIAN}

\section{a) Hasil analisis kualitatif Hukum Islam}

Dalam dunia kerja, Islam telah membahas beberapa hal yang berkaitan dengan perburuhan. Diantaranya tentang hak dasar buruh, dalam Al-Qu'ran: Hak buruh atas upah kerjanya, hak atas upah sesuai dengan nilai kerjanya, hak sebagai nafkah keluarga, hak bekerja sebagai kemampuannya, hak atas waktu istirahat, hak atas perlindungan kekerasan, hak jaminan sosial, dan penghargaan masa kerja.

Dari sisi majikan digariskan beberapa kewajiban, diantaranya: baik kepada buruh, membangun kesetaraan dengan buruh, bertanggung jawab terhadap kesehatan buruh, jujur dalam menjalankan usaha, bertanggung jawab dalam tugas, larangan menumpuk modal/membekukannya demi kepentingan pribadi, larangan penyalahgunaan kekayaan, dan menghindari berlebih-lebihan, efektif dalam menjalankan usaha. 
Menurut Al-Syarbini, ayah tidak boleh mengajari pekerjaan yang justru menghinakan anaknya, dan tidak boleh bagi orang tua mengajari anaknya pekerjaan yang buruk, demi menjaga kemaslahatan anak, wajib bagi orang tua, keluarga dan wali mendidik dan mengajari anakanaknya.

\section{b) Hasil analisis Kualitatif menurut Hukum Positif}

Di dalam Undang-Undang Tentang Tenaga Kerja dijelaskan bahwa: Pengusaha dilarang mempekerjakan anak dalam keadaan apapun dan dengan alasan apapun, pengusaha tetap tidak boleh mempekerjakan anak dibawah umur. Dan menyebutkan bahwa anak-anak boleh dipekerjakan dengan syarat mendapat izin orang tua dan bekerja maksimum tiga jam dalam sehari.

Praktik mempekerjakan anak yang dilakukan tidak lagi memperhatikan umur, pekerjaan, keselamatan dan kesehatan anak. Pekerja anak atau anak yang dipekerjakan terutama di bidang pertanian atau yang bekerja bersama-sama dengan orang yang lebih dewasa, tidak dibedakan baik dari segi tempat, pekerjaan dan lama waktu bekerja. Anak di bawah usia 18 (delapan belas) tahun tidak dapat dkatakan cakap hukum dan perbuatan yang dilakukannya belum mencapai kriteria perbuatan atau tindakan hukum. Hal ini dikarenakan keterbatasan pengetahuan tentang pekerjaan, yang mengharuskan menandatangani kontrak kerja, dan tentunya sudah dipersipkan oleh pihak-pihak yang mempekerjakan anak tersebut. Dan juga belum dapat mengetahui dampaknya pekerjaan terhadap perkembangan dan pertumbuhannya.

\section{DISKUSI}

Dalam hukum Islam ada yang dinamakan kecakapan hukum, yang berarti kelayakan seseorang untuk menerima hukum dan bertindak hukum atau sebagai kelayakan seseorang untuk menerima hak dan kewajiban. Artinya anak di sini belum mempunyai kewajiban, dikarenakan masih merupakan tanggung jawab orang tuanya atau ayahnya, sesuai dengan firman Allah SWT QS Al-Baqarah: 233: 


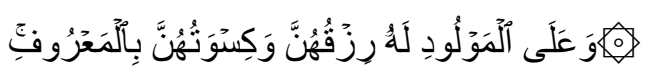

Artinya: Dan kewajiban ayah memberi Makan dan pakaian kepada Para ibu dengan cara ma'ruf.

Landasan kewajiban ayah menafkahi anak selain karena hubungan nasab, juga karena kondisi anak yang belum mandiri dan sedang membutuhkan pembelajaran, hidupnya tergantung kepada adanya pihak yang bertanggungjawab menjamin nafkah hidupnya. Orang yang paling dekat dengan anak adalah ayah dan ibunya, apabila ibu bertanggung jawab pada pengasuhan anak di rumah, maka ayah bertanggung jawab mencarikan nafkah anaknya. Dengan demikian, bahwasanya kita ketahui begitu besarnya tanggung jawab orang tua terhadap anaknya, sehingga masih berbentuk janinpun dia sudah harus dijaga. Sebagaimana sabda Rasulullah saw: "Apabila ada seorang di antara wanita membunuh secara sengaja, ia tidak boleh dijatuhi hukuman mati sampai ia melahirkan anaknya, jika ia memang sedang hamil. Dan bilamana seorang wanita berzina, ia tidak boleh dirajam sampai ia melahirkan anaknya jika ia sedang hamil dan sampai ia selesai merawatnya." (HR Ibnu Majah).

Rasulullah mengajarkan untuk mengungkapkan kasih sayang tidak hanya secara verbal, tetapi juga dengan perbuatan. Pada suatu hari Umar menemukan beliau saw merangkak di atas tanah, sementara dua orang anak kecil berada di atas punggungnya. Umar berkata:"Hai anak, alangkah baiknya rupa tungganganmu itu." Yang ditunggangi menjawab:"Alangkah baiknya rupa para penunggangnya". Betapa indah susasana penuh kasih sayang antara Rasul saw dengan cucu-cucu beliau.

Seorang ahli (Dorothy Law Nolte) berujar:"Jika anak dibesarkan dengan kasih sayang dan persahabatan, ia belajar menemukan cinta dalam kehidupan." Bila orang tua gagal mengungkapkan rasa sayang pada anak-anaknya, anak-anak tersebut tak akan mampu menyatakan sayangnya kepada orang lain. Dengan demikian, dalam keluarga tersebut tidak akan terjadi sifat individualistic dengan mementingkan diri sendiri. Mulai dari sikap orang tua terhadap anak dan sikap anak terhadap orang 
tuanya. Dalam hal ini orang tua mempekerjakan anaknya dan tidak mendengarkan apa yang menjadi keinginan anaknya (Sofyan, 2009).

Dalam praktik mempekerjakan anak, menurut Islam justru di sini menyempitkan hati seorang anak, mengesploitasi anak dari pertemanan sebayanya, membuat anak lebih cepat menjadi orang dewasa dari segi pola pikirnya, yang di sini justru bertentangan dengan tugas perkembangan seusiannya yaitu masih bermain, belajar, dibelai dengan penuh kasih sayang oleh orang tuanya. Oleh karena itu Islam melarang mempekerjakan anak, apalagi dengan tujuan untuk mendapatkan uang, tetapi jika untuk pembelajaran diizinkan dengan syarat ada pengawasan, terjamin keselamatannya, terjamin kesehatannya, bekerja paling lama 3 jam, masih tetap sekolah dan bekerja seperlunya saja artinya tidak setiap hari. Hal ini sangat bertentangan dengan pasal 45 dalam UU Perkawinan, dimana disebutkan bahwa kedua orang tua wajib memelihara mendidik anak-anak mereka sebaik-baiknya, yang berlaku sampai anak mampu berdiri sendiri.

Dalam sebuah hadis yang berbunyi:" Laa dhorooro wa laa diroor "artinya“" tidak boleh memberikan mudharat pada diri sendiri dan memudhoratkan orang lain. Makna yang terkandung di dalam hadis ini bahwa dalam hubungannya dengan praktik mempekerjakan anak, baik orang tua, majikan, pemimpin di tempat kerja yang lainnya atau orang dewasa lainnya, janganlah membuat dirinya menjadi rugi dan juga jangan merugikan orang lain. Artinya di sini anak akan tereksploitasi dan hal itumerugikan anak, sedangkan orang tua atau orang dewasa yang lainnya akan mendapatkan dosa, dan ini juga merugikan.

Dalam Al-Qur'an terdapat larangan tindakan diskriminatif (ahabbu ilaa.....min) pada anak, seperti digambarkan dalam surat Yusuf ayat 8 yang berbunyi:

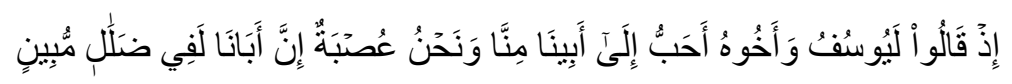

Artinya adalah (yaitu) ketika mereka berkata: "Sesungguhnya Yusuf dan saudara kandungnya (Bunyamin) lebih dicintai oleh ayah kita dari pada kita sendiri, Padahal kita (ini) adalah satu golongan (yang kuat). Sesungguhnya ayah kita adalah dalam kekeliruan yang nyata. 
Nabi Ya'kub lebih mencintai Yusuf daripada anaknya yang lain. Akibatnya, saudarasaudaranya maker pada Yusuf, dengan melakukan tindakan kekerasan kepadanya yaitu memasukkan Yusuf ke dalam sumur. Ayat ini mengajarkan kepada kita agar tidak diskriminatif dalam memperlakukan anak, lebih-lebih pada anak yatim. Allah berfirman dalam surat An-Nisa' ayat 127 yang artinya: "dan tentang anak-anak yang masih dipandang lemah. (dan (Allah menyuruh kamu) supaya kamu mengurus anak-anak yatim secara adil. dan kebajikan apa saja yang kamu kerjakan, Maka Sesungguhnya Allah adalah Maha mengetahuinya".

Berhubungan dengan hadis di atas, kita harus mengutamakan kepentingan yang terbaik bagi anak, maksudnya adalah bahwa dalam semua tindakan yang menyangkut anak yang dilakukan oleh pemerintah, masyarakat, badan legislative, badan yudikatif, maka kepentingan yang terbaik bagi anak harus menjadi pertimbangan utama (pasal 3 ayat 1 konvensi hak anak).

Pandangan Hukum Positif mengenai praktik mempekerjan anak harus melihat dari hukum privat tentang pengertian perjanjian, perjanjian dapat dipahami bahwa : "Suatu perjanjian adalah suatu perbuatan dengan mana satu orang atau lebih mengikatkan dirinya terhadap satu orang lain atau lebih" (Supriyadi, 2000).

Dari pengertian di atas dapat ditarik benang merahnya bahwa dalam sebuah perjanjian melahirkan perbuatan atau lebih tepatnya perbuatan atau tindakan hukum dengan satu orang atau lebih karena perbuatan tersebut membawa akibat hukum bagi para pihak yang memperjanjikan dan selnjutnya mempunyai ikatan dengan satu orang atau lebih tersebut karena di dalam perjanjian terdapat unsur janji yang diberikan oleh pihak yang satu kepada pihak yang lain.

Dalam perjanjian ini orang terikat kepada akibat hukum yang muncul karena kehendaknya sendiri. Hal ini bila disandingkan dengan pekerja anak di bawah umur tentunya melanggar ketentuan yang ada, karena dalam sebuah perjanjian ada syarat-syarat yang harus dipenuhi sebagaimana tertera dalam KUH Perdata Pasal 1320 sebagai berikut: 
1. Sepakat mereka yang mengikatkan dirinya; kata sepakat harus benar-benar dilandasi dengan kesadaran penuh seseorang untuk melakukan perjanjian, sehingga tidak ada keterpaksaan satu sama lain yang akan merugikan satu sama lainnya. Karena tiada sepakat yang sah apabila diberikan karena kekhilafan, atau diperolehnya dengan paksaan dan penipuan (Pasal 1321 KUH Perdata) adanya penipuan yang tidak hanya mengenai kebohongan tetapi juga adanya tipu muslihat (Pasal $1328 \mathrm{KUH}$ Perdata). Terhadap perjanjian yang dibuat atas dasar "sepakat" berdasarkan alasan-alasan tersebut, dapat diajukan pembatalan.

2. Cakap untuk membuat perikatan; kata "cakap" dapat dikatakan sudah memenuhi persyaratan untuk berbuat tindakan hukum dalam Pasal 1330 KUH Perdata menentukan yang tidak cakap untuk membuat perikatan adalah (Orang-orang yang belum dewasa), (mereka yang ditaruh dibawah pengampuan), (Orang-orang perempuan, dalam hal-hal yang ditetapkan oleh undang-undang, dan pada umumnya semua orang kepada siapa undang-undang telah melarang membuat perjanjian perjanjian tertentu), (Suatu hal tertentu.dalam hal ini Sesuatu yang diperjanjikan haruslah suatu hal atau barang yang cukup jelas, setidak-tidaknya dapat ditentukan. Jadi tidak boleh samar-samar. Hal ini penting untuk memberikan jaminan atau kepastian kepada pihak-pihak dan mencegah timbulnya kontrak fiktif).

3. Suatu sebab atau causa yang halal. Sahnya causa dari suatu persetujuan ditentukan pada saat perjanjian dibuat. Perjanjian tanpa causa yang halal adalah batal demi hukum, kecuali ditentukan lain oleh undang-undang.

Dari uraian di atas, sebuah konsep ideal dari sebuah aturan, sudah cukup menjamin akan hakhak anak dalam mengembangkan diri mereka, namun yang menjadi problema saat ini adalah belum sepenuhnya terealisasi, dan bahkan ironisnya bahwa praktik mempekerjakan anak masih menjadi pemandangan yang tidak lazim dilihat, anak-anak memakai baju yang bebas, padahal saat itu adalah jam sekolah, dan mereka berada di perusahaan yang bergerak dibidang industri, perkebunan, hingga warung-warung dan toko-toko kecil sekalipun, rumah tangga dan lain-lain. Sehingga dapat 
dibayangkan bagaimana masa depan anak tersebut, dengan persiapan mental dan ilmu yang belum cukup yang sudah dipaksakan untuk dipraktekkan di tempat-tempat mereka bekerja, dan juga anakanak tersebut masih memerlukan perlindungan dari orang lain, dan kondisi ini terpaksa harus melindungi diri sendiri.

Di dalam UU Tentang Tenaga Kerja dijelaskan bahwa: Pengusaha dilarang mempekerjakan anak (UURI, 2003). Dalam keadaan apapun dan dengan alasan apapun pengusaha tidak oleh mempekerjakan anak dibawah umur. Hal ini tertuang di dalam pasal 68- 75 UU Ketenaga kerjaan yang berbunyi:

1. Pengusaha dilarang mempekerjakan anak.

2. Ketentuan sebagaimana dimaksud dalam Pasal 68 dapat dikecualikan bagi anak yang berumur antara 13 (tiga belas) tahun sampai dengan 15 (lima belas) tahun untuk melakukan pekerjaan ringan sepanjang tidak mengganggu perkembangan dan kesehatan fisik, mental, dan sosial”.

3. Pengusaha yang mempekerjakan anak pada pekerjaan ringan sebagai-mana dimaksud dalam ayat (1) harus memenuhi persyaratan :izin tertulis dari orang tua atau wali; perjanjian kerja antara pengusaha dengan orang tua atau wali; waktu kerja maksimum 3 (tiga) jam; dilakukan pada siang hari dan tidak mengganggu waktu sekolah; keselamatan dan kesehatan kerja; adanya hubungan kerja yang jelas; dan menerima upah sesuai dengan ketentuan yang berlaku.

4. Ketentuan sebagaimana dimaksud dalam ayat (2) huruf a, b, f, dan g dikecualikanbagi anak yang bekerja pada usaha keluarganya".

5. Anak dapat melakukan pekerjaan di tempat kerja yang merupakan bagian dari kurikulum pendidikan atau pelatihan yang disahkan oleh pejabat yang berwenang”.

6. Anak sebagaimana dimaksud dalam ayat (1) paling sedikit berumur 14 (empat belas) tahun”.

7. Pekerjaan sebagaimana dimaksud dalam ayat (1) dapat dilakukan dengan syarat:

8. diberi petunjuk yang jelas tentang cara pelaksanaan pekerjaan serta bimbingan dan pengawasan dalam melaksanakan pekerjaan; dan 
9. diberi perlindungan keselamatan dan kesehatan kerja.

10. Anak dapat melakukan pekerjaan untuk mengembangkan bakat dan minatnya".

11. Pengusaha yang mempekerjakan anak sebagaimana dimaksud dalam ayat (1) wajib memenuhi syarat: di bawah pengawasan langsung dari orang tua atau wali; waktu kerja paling lama 3 (tiga) jam sehari; dan kondisi dan lingkungan kerja tidak mengganggu perkembangan fisik, mental, sosial, dan waktu sekolah.

12. Ketentuan mengenai anak yang bekerja untuk mengembangkan bakat dan minat sebagaimana dimaksud dalam ayat (1) dan ayat (2) diatur dengan Keputusan Menteri”.

13. Dalam hal anak dipekerjakan bersama-sama dengan pekerja/buruh dewasa, maka tempat kerja anak harus dipisahkan dari tempat kerja pekerja/buruh dewasa.

Mempekerjakan anak, dilihat secara psikologi akan mengganggu perkembangan anak-anak yang dipekerjakan. Di mana anak-anak di bawah usia 18 tahun tersebut masih mencari jati diri, harus memenuhi berbagai tugas-tugas perkembangan sesuai dengan usianya. Dan juga menurut Hendra (2011) bahwa hal semacam ini dapat menyebabkan terjadinya penyimpangan sosial dikarenakan longgar atau tidaknya nilai dan norma, sosialisasi yang tidak sempurna dan sosialisasi sub kebudayaan yang menyimpang (Hendra, 2011).

Sebagai contoh bahwa anak yang dipekerjakan jelas tidak bisa bersosialisasi, baik yang bekerja sebagai PRTA, PSKA, pemulung, pengemis, buruh dan yang lainnya, sudah jelas tidak ada yang namanya nilai dan norma bagi anak, dan juga bagaimana anak dapat bersosialisasi, jika anak-anak tersebut harus menyelesaikan pekerjaan yang sudah dibebankan kepadanya.

Emosi memegang peranan penting dalam kesuksesan hubungan anak dengan teman sebaya (Hubbard dalam Santrok, 2007). Anak-anak yang moody dan memiliki emosi negatif akan mengalami penolakan yang lebih besar dari teman sebaya mereka. Sedangkan anak-anak dengan emosi positif akan menjadi populer (Strocker \& Dunn dalam Santrok, 2007). Dalam hubungannya dengan anak 
yang dipekerjakan, secara tidak langsung akan mengganggu hubungan anak dengan teman sebaya, dan anak cenderung menjadi apatis dengan lingkungan, hal ini dikarenakan beban pekerjaan yang mengharuskan seperti ini.

Beberapa perubahan yang penting dalam perkembangan emosi anak masa kanak-kanak madya dan akhir adalah :

a. Peningkatan kemampuan untuk memehami emosi kompleks, misalnya kebanggaan dan rasa malu. Emosi-emosi ini menjadi lebih terinternalisasi (self-generated) dan terintegrasi dengan tanggung jawab personal.

b. Peningkatan pemahaman bahwa mungkin saja seseorang mengalami lebih dari satu emosi dalam situasi tertentu.

c. Peningkatan kecenderungan untuk lebih mempertimbangkan kejadian-kejadian yang menyebabkan reaksi emosi tertentu.

d. Peningkatan kemampuan untuk menekan atau menutupi reaksi emosional yang negatif.

e. Penggunaan strategi personal untuk mengalihkan perasaan tertentu, seperti mengalihkan atensi atau pikiran ketika mengalami emosi tertentu (Thompson \& Goodvin dalam Santrok, 2007).

Anak yang sudah dipekerjakan sudah jelas kurang mendapatkan kasih sayang dari orang tuanya. Hal ini berakibat buruk pada anak tertentu. Bowbly (Santrok,2007) menyatakan bahwa attachment yang insecure, kurangnya cinta kasih dan afeksi dalam pengasuhan anak, atau kehilangan orang tua pada masa anak-anak, menyebabkan anak mengembangkan skema negatif. Skema ini terus akan dibawa dan mempengaruhi bagaimana pengalaman yang akan datang akan diiterpretasi. Ketika pada pengalaman yang akan datang anak juga mengalami kehilangan tertentu, anak akan menginterpretasikan kehilangan ini sebagai kegagalan dalam membina hubungan positif, dan biasanya hal ini akan menyulut timbulnya depresi. 


\section{KESIMPULAN DAN SARAN}

Berdasarkan deskripsi dan analisis sebelumnya, maka dapat disimpulkan sebagai berikut:

1. Faktor-faktor yang menyebabkan terjadinya praktik mempekerjakan anak adalah faktor kemiskinan, Tracfiking, rendahnya pendidikan ,kurangnya pengetahuan bagi anak akan membuat majikan dapat memberikan upah yang rendah, dan secara otomatis tidak terjadinya posisi tawar, artinya berapapun upahnya bagi anak sebagai pembantu rumah tangga akan diterima oleh anak, selain itu anak mudah diatur, mudah dieksploitasi waktu dan tenaganya,serta tidak ada payung hukum yang jelas.

2. Bentuk-bentuk dari praktik mempekerjakan anak yang ada di Kota Bandar Lampung ini adalah pekerja seks komersil yang bisa disebut dengan AYLA (anak yang dilacurkan), pembantu rumah tangga (PRTA), buruh diperkebunan, buruh bangunan, pengemis, pemulung, buruh panggul di pelabuhan dan terminal, penjual koran, buruh cuci dan steam.

3. Mempekerjakan anak di dalam hukum positif dilarang dan itu telah dijelaskan dalam asas dan tujuan dari UU no 13 tahun 2003 dalam Pasal 2, dalam pasal 68 sampai pasal 74, yang menyatakan larangan mempekerjakan anak dan di tetapkan berbagai ketentuan-ketentuan jika terpaksa mempekerjakan anak. Dan juga terdapat di dalam Keputusan Menteri Tenaga Kerja dan Transmigrasi Republik Indonesia Nomor KEP-235/MEN/2003 tentang jenis- jenis pekerjaan yang membahayakan kesehatan, keselamatan dan atau moral anak.

4. Dalam Hukum Islam praktik mempekerjakan anak dilarang dan bahkan diharamkan yang didukung dalil naqli dan dalil 'aqli, sebelum ada dalil yang membolehkan, maka praktik mempekerjakan anak ini tetap dilarang, hal ini sesuai dengan Firman Allah SWT yang artinya “dan janganlah kamu menyusahkan mereka untuk menyempitkan hati mereka" dan hadis yang artinya "tidak boleh membuat mudarat dan tidak boleh menimbulkan mudarat bagi orang lain di dalam Islam". 
5. Di antara hukum positif dan hukum Islam, hukum Islamlah yang lebih fleksibel dikarenakan Tujuan syari’at Islam dalam menetapkan hukum-hukumnya adalah untuk kemaslahatan manusia secara keseluruhan, baik dunia maupun akhirat. Kemaslahatan tersebut dibagi dalam tiga kategori yaitu dharuriyat, hajiyyat dan tahsiniyat. Sedangkan dharuriyat tersebut terkenal dengan al Maqashid al-Khamsah (lima tujuan dasar syariat Islam), lima tujuan tersebut diarahkan untuk pemeliharan dari segala aspek (Kemaslahatan agama, jiwa, akal, keturunan dan harta benda). Jika kelima tujuan dasar ini terlaksana maka akan terbentuklah anak yang diharapkan.

6. Pengaruh praktik mempekerjakan anak terhadap perkembangan emosi anak bahwa anak akan mengembangkan skema negatif yang berpengaruh pada pengalaman yang akan diinterpretasikannya.

\section{DAFTAR PUSTKA}

Walgito, Bimo. (2002). Psikologi Sosial: Suatu Pengantar. Yogyakarta: Andi Offset

Departement Agama Republik Indonesia. (2010). Al-Qur'an Tajwid dan terjemahannya. Jawa Barat: CV Penerbit Diponegoro

Akhdiat, Hendra \& Marliani, Rosleny. (2011). Psikologi Hukum. Bandung: CV Pustaka Setia Santrock, John W. (2007). Perkembangan Anak, Edisi Kesebelas Jilid 2. Jakarta: Erlangga Koentjaraningrat. (1997). Metode-metode Penelitian Masyarakat. Jakarta: PT Gramedia Pustaka Utama

Moleong, Lexy J. (2005). Metodologi Penelitian Kualitatif: Cet. XXI. Bandung: PT. Remaja Rosdakarya

Sudjana, Nana \& Kusumah, Awal. (2000). Proposal Penelitian di Perguruan Tinggi. Bandung: PT Sinar Baru Algesindo

Willis, Sofyan S. (2009). Konseling Keluarga (Family Counceling): Suatu Upaya Membantu Anggota Keluarga Memecahkan Masalah Komunikasi di dalam Sistem Keluarga. Bandung: Alfabeta

Margono, S. (2000). Psikologi Belajar. Jakarta: Rineka Cipta

Tim Dosen fakultas Syari'ah. (2005). Buku Pedoman Penulisan Karya Ilmiah. Malang: Fakultas Syari'ah UIN

UU Republik Indonesia No 1 tahun 1974. (2012). Tentang Perkawinan. Yogyakarta: Rona Publishing Undang-undang RI No. 13 Tahun 2003 tentang Ketenagakerjaan. (2012). Jakarta: Sinar Grafika 